\title{
Identification of Algae as Water Quality Bioindicators in the Water Intakes of Two Municipalities of the Department of Quindío
}

\section{Identificación de Algas como Bioindicadores de Calidad de Agua en las Tomas de Agua de Dos Municipios del Departamento del Quindío}

DOI: $10.46932 / \mathrm{sfjdv2n4-046}$

Received in: March 1st, 2021

Accepted in: May 30th, 2021

\author{
José D. Quiñones \\ Biologist - Universidad del Quindío - UQ. \\ Full Address: Biology Program, School of Basic and Technological Sciences, Universidad Del Quindío. \\ Carrera 15 con calle 12 Norte, Armenia, Quindío, Colombia \\ E-mail: jdquinonesg@uqvirtual.edu.co@uqvirtual.edu.co \\ Alex M. Mopan \\ Biologist - Universidad del Quindío - UQ. \\ Full Address: Biology Program, School of Basic and Technological Sciences, Universidad Del Quindío. \\ Carrera 15 con calle 12 Norte, Armenia, Quindío, Colombia \\ E-mail: ammopanc@uqvirtual.edu.co
}

\section{RESUMEN}

En los ecosistemas acuáticos, la contaminación provoca una serie de modificaciones fisicoquímicas, repercuten en la composición y distribución de las comunidades presentes, las principales perturbaciones causadas en estos ecosistemas están relacionadas con la contaminación de origen doméstico, industrial, agrícola, minero y deforestación. Las algas son organismos que responden a impactos antropogénicos, convirtiéndose en buenos indicadores de calidad del agua, estos organismos, cuando se encuentran invariablemente en un ecosistema indican alguna condición medioambiental más o menos definida. El objeto de este estudio fue identificar los géneros de algas microscópicas indicadores de calidad del agua, presentes en las bocatomas de dos municipios del departamento del Quindío. El estudio se realizó en el departamento del Quindío, Colombia; en las bocatomas de los municipios de Salento y Montenegro, se realizaron dos salidas de campo en los meses de marzo y mayo para recolectar muestras de agua y medir las variables fisicoquímicas; Se realizó un análisis de comparación canónica entre la abundancia de algas y protozoos con respecto a las variables fisicoquímicas presentes, para esto se halló el índice de Shannon para los géneros de algas y protozoos encontrados en cada bocatoma. Se identificaron 20 géneros de Algas, 4 Protozoos y 3 Helmintos; se halló la presencia de coliformes totales para ambas bocatomas. Los géneros más abundantes de algas fueron Navicula y Oscilatoria los cuales se presentaron en todos los muestreos; los géneros de protozoos que mayor abundancia presentaron fueron Stylonychia y Colpidium y el género de Helmintos que se encontró para ambos muestreos fue Taenia.

Palabras claves: Impacto, Diversidad, Abundancia, Variables físicas y químicas

\section{ABSTRACT}

In aquatic ecosystems, pollution causes a series of physico-chemical modifications, affects the composition and distribution of the communities present, The main disturbances in these ecosystems are related to pollution from domestic, industrial, agricultural, mining and deforestation sources. Algae are organisms that respond to anthropogenic impacts, becoming good indicators of water quality, these organisms, when found invariably in an ecosystem indicate some more or less defined environmental 
condition. The aim of this study was to identify the microscopic algal genera, indicators of water quality, present in the mouths of two municipalities in the department of Quindío. The study was conducted in the department of Quindío, Colombia; in the mouths of the municipalities of Salento and Montenegro, two field trips were made in the months of March and May to collect water samples and measure physicochemical variables; A canonical comparison analysis was made between the abundance of algae and protozoa with respect to the physico-chemical variables present, for this the Shannon index was found for the genera of algae and protozoa found in each mouthpiece. We identified 20 genera of Algae, 4 Protozoa and 3 Helminths; we found the presence of total coliforms for both mouthfuls. The most abundant genera of algae were Navicula and Oscillator, which occurred in all the samples; The most abundant protozoa genera were Stylonychia and Colpidium, and the genus of Helminths found for both samples was Taenia.

Keywords: Impact, diversity, abundance, physical and chemical variables.

\section{INTRODUCTION}

In aquatic ecosystems, pollution by organic or inorganic sources causes a series of physicochemical modifications in water, which have an impact on the composition and distribution of the present communities (Roldan 1992). In aquatic organisms, the effects of submission to a toxic discharge, take over time of individual (biochemical and physiological) responses to population, community, and ecosystem responses. And the magnitude of the changes registered in the agencies, it depends on the duration of the duration of the initial conditions of the aquatic system, its intensity and nature (Pinilla 2000). The main sources of disturbances caused in aquatic ecosystems by man are related to pollution of domestic, industrial, agricultural, mining and deforestation origin, as the most important (Roldan 1999). The first efforts to determine the ecological damage caused by domestic and industrial waste in water currents were performed by Kolkwitz and Marson (1908-1909); thus creating the bases of the saprobic system widely used in European countries. Years later Patrick (1949-1950) proposes biological methods to evaluate the ecological conditions of currents, but only different water quality assessment methodologies were beginning to be used throughout the use of biological indicators.

Water constitutes a global problem in developing countries, where communicable diseases are a public health problem, being indispensable water for life, consumers have a satisfactory water supply, so that the provider must make the greatest effort as possible to supply water from the best quality according to the circumstances. For this reason, the first line of defense is the evaluation of the physical, chemical, and microbiological quality of the water supplied through the realization of analytical determinations and the surveillance and control of treatment processes. Surveillance and control of microbiological quality of water for human consumption should be routine and paramount activities.

Regardless of the agents that affect the quality of water for human consumption, it is necessary to take into account the risks caused by the poor protection of water sources, the inadequate water 
management during the process of treatment and lack of studies regarding the knowledge of the microorganisms present in it.

The quality of drinking water is a matter that is concerned in countries around the world, developing and developed, due to its impact on the health of the population. Infectious agents, such as pathogenic microorganisms, toxic chemicals are factors that increase the risk containing waterborne diseases.

It is considered that an organism is an indicator of quality when it is invariably found in an ecosystem of defined characteristics and when its population is considerably superior by means of percentage, or slightly alike to the rest of organisms with which it shares Habita (Roldán 1999). Specifically, bioindicators are organisms or communities of organisms whose presence indicates some more or less defined environmental condition (Wilson 1994) and respond physiological or being conducted to a broad spectrum of substances or toxic concentrations, whether they are organic or inorganic, natural or human influence (Ospina et al., 2004). In addition, the presence of a community in a given water body, is an unequivocal index of the conditions that are prevailing there and that fluctuations of contaminations that may arise are not strong enough to cause significant change in it (Roldan 1999).

\section{OBJECTIVES}

\section{- $\quad$ Main objective}

Identify the genres of microscopic algae Indicators of water quality, present in the Water Intakes of the Municipalities of Salento and Montenegro in the department of Quindío.

\section{- $\quad$ Specific objectives}

- To carry out a comparison between indicator algae and other bioindicators water quality microorganisms (Escherichia coli, mesophilic aerobics, and total coliforms).

- To carry out a comparison of diversity of water quality algae between the two municipalities of Salento and Montenegro.

- To determine the existence of a possible correlation between algae and physicochemical variables.

Theoretical Framework

In Colombia, the established microbiological parameters are within the 2007 resolution 2115 of the Ministry of Social Protection, which establish the indicator microorganisms to determine the quality of water such as total coliforms, Escherichia coli, Mesophilus aerobics, which are general indicators of contamination and possible presence of pathogenic microorganisms with possible occurrence of acute diseases such as protozoan parasites. But there are other bioindicators of water quality different from aquatic macroinvertebrates that are not included in the 1975 Decree 1575 of Colombia, as are algae; Very 
old organisms that have chlorophyll but are not plants because they do not generate tissues or organs, their structural organization is talophyte type and are autotrophic organisms that practically live in all ecosystems on the planet, presenting a wide range of sizes, shapes, structure Cell and ecological and physiological strategies (González 1987, Cabioc'h et al., 1995, Peña et al., 2005). In different studies of other countries, algae are widely used as bioindicators of water quality, since they are easily sampled (Levine 1984, Wilcox et al., 1998) and indicate in a clear way the presence of pollutants and this is It is that algae communities respond to anthropogenic impacts, as an excess of nutrients and toxic substances, thus becoming good indicators of changes in water quality (Wang and Lewis 1997).

Costa et al (1999) and Schiewer et al., (2000) in their studies consider a series of specific attributes to catalog algae as good ecological indicators; Short life cycles make appropriate indicators for short-term impacts; The fixing habits of most species make them affected directly by physical and chemical changes in water bodies; In addition, because it is primary producers, they are sensitive to pollutants that have no effect on heterotrophic agencies (Levine 1984, Wilcox et al., 1998). The most used are the diatoms, which are part of the phytoplankton of both marine and sweet-time media showing short-term changes and rapid responses to these changes such as the medium's trophic state according to its abundance (from ultrapolyigotrophic to hyperutrophic). In Colombia the diatoms have been used to be able to know the physicochemical conditions of the past (Lozano et al., 1999, Vélez et al., 2003, 2005a, 2005b) the current physicochemical conditions (Díaz and Rivera 2004, Montoya et al., 2008; Ramírez and Silver 2008, Castro 2009), and recently, it has begun to include some species as bioindicators of water quality in rivers (Abuhatab and Donato 2012, Morales et al., 2010).

\section{MATERIALS AND METHODS}

Study area

The study was held in the department of Quindío, specifically in the water intakes of the Municipalities of Salento ( $4^{\circ} 37^{\prime} 53$ "N $75^{\circ} 32^{\prime} 37^{\prime \prime} \mathrm{W}$ ) and Montenegro (4 ${ }^{\circ} 34^{\prime} 39.2$ "N $75^{\circ} 44^{\prime} 13.6^{\prime \prime} \mathrm{W}$ ) (Figure 1). The municipality of Salento is located at the northerner of the department of Quindío, presenting heights ranging from 2000 (MSNM) and 4750 (MSNM) with an average temperature of $18^{\circ}$ C; The Municipality of Montenegro is located in the western part of the Quindío Department at 1300 (MSNM) with an average temperature of $23^{\circ} \mathrm{C}$. 
Figure 1: Map of location of the study area. Water intakes of the municipalities of Salento and Montenegro, Quindío, Colombia.

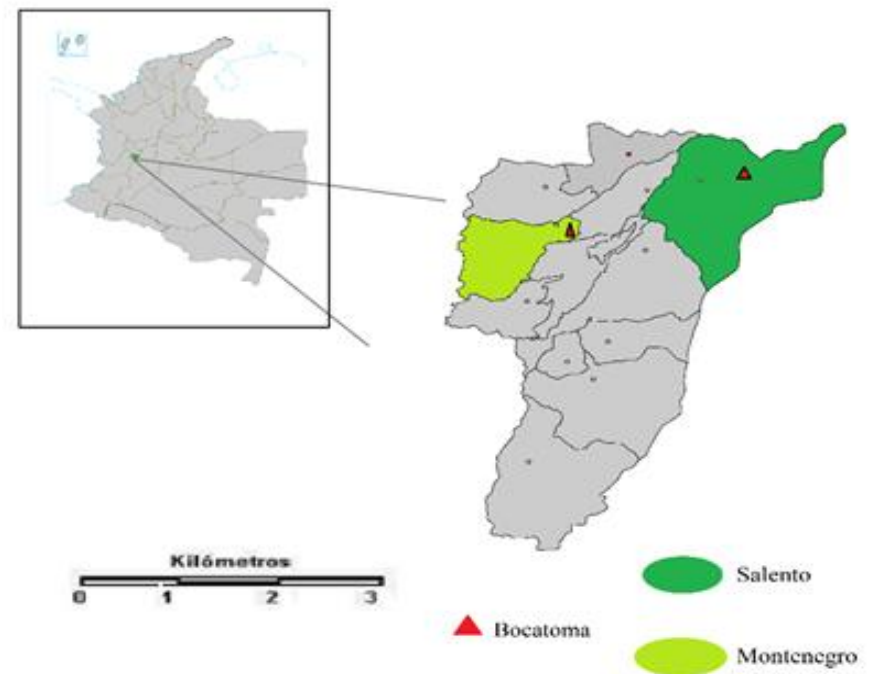

Field phase.

For this study, two samples were held during the months of March and May for the two water intakes, in order to collect the samples of water and measure the physicochemical variables in different time conditions since for the beginning of the month of March it was season of Summer and by the end of May was winter season.

The physicochemical variables taken were $\mathrm{pH}$, conductivity, dissolved solids, and temperature for this a portable multiparametric meter was used. For the queue of the water samples to analyze the presence of algae and protozoa; From each water intake and in each sampling 10 liters of water were taken in sterilized plastic cars. In addition to analyzing the presence of total coliforms and E. coli a liter of separate water was taken in a glass bottle, the samples were transported in petrolatum fridges refrigerated with gels at $4{ }^{\circ} \mathrm{C}$ to the Biomedical Research Center at Universidad del Quindío where the samples were saved at $4{ }^{\circ} \mathrm{C}$ for its subsequent processing of each of them.

Laboratory phase.

For the analysis of the total coliforms and E. coli, the samples were sent to the water laboratory of the Faculty of Engineering of the University of Quindío by means of the membrane filtration method. For the analysis of algae and protozoa, the method of (sedimentation and concentration of the sample) was performed by the parasitology laboratory of the University of Quindío, for the algae were left $15 \mathrm{ml}$ of the sample and for the protozoa were left $5 \mathrm{ml}$ of the sample; In addition to the protozoan sample, Ritchie was performed. For the observation of the algae present in the water samples, $10 \%$ iodine was added and the inverted microscope (AMSCOPE) was used by observing 40x, the photographic registration of each morph found for later identification was performed. For the observation of the protozoa present in the 
waters, $10 \%$ Iodine was also used, and the optical microscope was used by observing 40x and 100x, the photographic registration of each morph found for later identification was performed.

For the identification of algae genres, taxonomic keys and the database (Manaki Whenu - Landcare Research) were used and corroborated with specialists in this group. For the identification of the protozoa, identification guides were used and they were corroborated with a specialist in this group.

Statistical Analysis.

A canonical comparison analysis was performed between the abundance of algae and protozoa with respect to the physicochemical variables present for both water intakes. In order to perform the analysis, the Shannon Index (true diversity) was found for the genres of algae and protozoa found in every water intake.

\section{RESULTS AND DISCUSSION}

20 genders of algae were identified (Table 1 and 2); 5 Genres of protozoa (Table 3) and 3 genera of Helminths (Table 4) in the 2 water intakes. The most abundant genres of algae were Navicula, oscillatory, Meally, Cymbella and Ankistrodesmus. The genres of more abundant protozoos and that were recorded in all samples were Stylonychia, and Colpidium, the most abundant helminth genre was schistosome. The genres of algae that were recorded for all samples were navicula and oscillatory.

In the samples analyzed for coliforms and E. coli it is observed that for both places it is significant the presence of these microorganisms (Table 5) because they are not within the parameters established by Resolution 2115 of 2007 where the maximum values accepted are ( 0 UFC / $100 \mathrm{~cm} \mathrm{3),}$ for this study.

Table 1. Alga genres found in the Salento Water Intake (M1 = first sampling, $\mathrm{m} 2$ = second sampling; $\mathrm{B}=$ good quality water; $\mathrm{m}=$ water of poor quality; $\mathrm{R}=$ wastewater).

\begin{tabular}{|c|c|c|c|c|c|c|c|}
\hline Common name & Family group & Genre & $1 \mathrm{M}$ & $2 \mathrm{M}$ & $\mathrm{B}$ & M & $\mathrm{R}$ \\
\hline Cyanobacteria & Nostocaceae & Anabaena & $X$ & & & & $\mathrm{X}$ \\
\hline Green algae & Selenastraceae & Ankistrodesmus & $\mathrm{X}$ & $\mathrm{X}$ & & & \\
\hline Diatom & Rhizosoleniaceae & Dactyliosolen & $\mathrm{X}$ & & & $\mathrm{X}$ & \\
\hline Diatom & Naviculaceae & Euglena & $\mathrm{X}$ & & $\mathrm{X}$ & & \\
\hline Diatom & Eunotiaceae & Eunotia & $\mathrm{X}$ & & & $\mathrm{X}$ & \\
\hline Diatom & Naviculaceae & Navicula & $\mathrm{X}$ & $\mathrm{X}$ & & & \\
\hline Cyanobacteria & Oscillatoriaceae & Oscillatoria & $\mathrm{X}$ & $\mathrm{X}$ & $\mathrm{X}$ & & \\
\hline Diatom & Pinnulariaceae & Pinularia & $\mathrm{X}$ & & $\mathrm{X}$ & & \\
\hline Blue-Green Algae & Spirulinaceae & Spirulina & $\mathrm{X}$ & & & $\mathrm{X}$ & \\
\hline Green Algae & Closteriaceae & Closterium & & $X$ & & & \\
\hline Green Algae & Hydrodictyaceae & Pediastrum & & $\mathrm{X}$ & & & \\
\hline
\end{tabular}




\section{SOUTH FLORIDA}

SOUTH FLORIDA

Table 2. Algae Genres found in Montenegro's Water Intake (M1 = First Sampling, M2 = Second Sampling; B = Good Quality Water; $\mathrm{M}=$ Poor Water; $\mathrm{R}=$ Wastewater).

\begin{tabular}{|c|c|c|c|c|c|c|c|}
\hline Common name & Family group & Genre & $1 \mathrm{M}$ & $2 \mathrm{M}$ & $\mathrm{B}$ & M & $\mathrm{R}$ \\
\hline Cyanobacteria & Nostocaceae & Anabaena & $\mathrm{X}$ & & & & $\mathrm{X}$ \\
\hline Green Algae & Selenastraceae & Ankistrodesmus & $X$ & & & $X$ & \\
\hline Dinoflagellates & Ceratiaceae & Ceratium & $\mathrm{X}$ & & & & $X$ \\
\hline Green Algae & Closteriaceae & Closterium & $X$ & $X$ & & & $\mathrm{X}$ \\
\hline Diatom & Cymbellaceae & Cymbella & $\mathrm{X}$ & $X$ & & & \\
\hline Diatom & Fragilariaceae & Fragilaria & $\mathrm{X}$ & & & & $\mathrm{X}$ \\
\hline Diatom & Gomphonemataceae & Gomphonema & $X$ & $\mathrm{X}$ & & & \\
\hline Diatom & Pleurosigmataceae & Gyrosigma & $X$ & $\mathrm{X}$ & & & $\mathrm{X}$ \\
\hline Diatom & Melosiraceae & Melosira & $\mathrm{X}$ & $\mathrm{X}$ & & & \\
\hline Diatom & Naviculaceae & Navicula & $X$ & $\mathrm{X}$ & & & \\
\hline Diatom & Bacillariaceae & Nitzchia & $X$ & & $\mathrm{X}$ & & \\
\hline Cyanobacteria & Oscillatoriaceae & Oscillatoria & $\mathrm{X}$ & $\mathrm{X}$ & $\mathrm{X}$ & & \\
\hline Diatom & Pinnulariaceae & Pinularia & $X$ & & $\mathrm{X}$ & & \\
\hline Green Algae & Zygnemataceae & Spirogynas & $X$ & & & $\mathrm{X}$ & \\
\hline Diatom & Fragilariaceae & Synedra & $X$ & & & $\mathrm{X}$ & \\
\hline Diatom & Bacillariaceae & PseodoNitzchia & & $\mathrm{X}$ & & & \\
\hline Blue-Green Algae & Spirulinaceae & Spirulina & & $X$ & & & \\
\hline
\end{tabular}

Table 3. Genres of protozoa found in the Water Intake in both Water Intakes $(1 \mathrm{~m}=$ first sampling; $2 \mathrm{~m}=$ second sampling; $\mathrm{s}=$ Salt-skentingWater Intake.

\begin{tabular}{|c|c|c|c|c|c|}
\hline Common name & Group Family & Genre & $1 \mathrm{M}$ & $2 \mathrm{M}$ & $\mathrm{S}$ \\
\hline Ciliated protozoa & Tetrahymenidae & Colpidium & $X$ & $X$ & $X$ \\
\hline Ciliated protozoa & Oxytrichidae & Stylonichia & $X$ & $X$ & $X$ \\
\hline Ciliated protozoa & Entamoebidae & Entamoeba & & $X$ & $X$ \\
\hline Ciliated protozoa & Parameciidae & Paramecium & & $X$ & $X$ \\
\hline Ciliated protozoa & Prorodontidae & Pseudoprorodon & & $X$ & $X$ \\
\hline
\end{tabular}

Table 4. Genres of helminths found in both Water Intakes $(1 \mathrm{M}=$ first sampling; $2 \mathrm{~m}=$ second sampling; $\mathrm{s}=\mathrm{SALENTO}$ WATER INTAKE; $\mathrm{M}=$ WATER INTAKE MONTENEGRO)

$\begin{array}{ccccccc}\text { Common name } & \text { Family group } & \text { Genre } & 1 \mathrm{M} & 2 \mathrm{M} & \mathrm{S} & \mathrm{M} \\ \text { Helminth } & \text { Taeniidae } & \text { Taenia } & X & & X & \\ \text { Helminth } & \text { Taeniide } & \text { Taenia } & & X & & X \\ \text { Helminth } & \text { Schistosomatidae } & \text { Esquistosoma } & & X & X & X \\ \text { Nematode } & \text { Ascarididae } & \text { Ascaris } & & X & & X\end{array}$


Table 5. Results of the analysis of total coliforms and E. coli.

\begin{tabular}{|c|c|c|c|c|c|}
\hline \multicolumn{6}{|c|}{ SALENTO WATER INTAKE } \\
\hline Sample & Units & $\begin{array}{l}\text { Analysis } \\
\text { method }\end{array}$ & Result & Uncertainity & $\begin{array}{l}\text { Maximum } \\
\text { values } \\
\text { accepted }\end{array}$ \\
\hline $\begin{array}{c}\text { Total of } \\
\text { coliforms }\end{array}$ & $\begin{array}{c}\mathrm{UFC} / 100 \\
\mathrm{ml}\end{array}$ & $\begin{array}{l}\text { Filtration } \\
\text { by } \\
\text { membrane }\end{array}$ & 292 & 0.95 & $\begin{array}{c}0 \\
\mathrm{UFC} / 100 \\
\mathrm{~cm} 3\end{array}$ \\
\hline E. Coli & $\begin{array}{c}\text { UFC/100 } \\
\mathrm{ml}\end{array}$ & $\begin{array}{l}\text { Filtration } \\
\text { by } \\
\text { membrane }\end{array}$ & 96 & 0.95 & $\begin{array}{c}0 \\
\mathrm{UFC} / 100 \\
\mathrm{~cm} 3\end{array}$ \\
\hline \multicolumn{6}{|c|}{ MONTENEGRO WATER INTAKE } \\
\hline Sample & Units & $\begin{array}{l}\text { Analysis } \\
\text { method }\end{array}$ & Result & Uncertainity & $\begin{array}{l}\text { Maximum } \\
\text { values } \\
\text { accepted }\end{array}$ \\
\hline $\begin{array}{c}\text { Total of } \\
\text { coliforms }\end{array}$ & $\begin{array}{c}\mathrm{UFC} / 100 \\
\mathrm{ml}\end{array}$ & $\begin{array}{l}\text { Filtration } \\
\text { of } \\
\text { membrane }\end{array}$ & $1,04 \times 10^{3}$ & 0.95 & $\begin{array}{c}0 \\
\mathrm{UFC} / 100 \\
\mathrm{~cm} 3\end{array}$ \\
\hline E. Coli & $\begin{array}{c}\mathrm{UFC} / 100 \\
\mathrm{ml}\end{array}$ & $\begin{array}{l}\text { Filtration } \\
\text { of } \\
\text { membrane }\end{array}$ & 780 & 0.95 & $\begin{array}{c}0 \\
\text { UFC/100 } \\
\mathrm{cm} 3\end{array}$ \\
\hline
\end{tabular}

Canonical analysis between the diversity of algae and physicochemical variables (Table 6) gave a negative value for the conductivity variable (US_cm) this indicates that if the conductivity in water increases, the abundance of algae is going to diminish. The variable with the highest positive value was that of dissolved solids (PPM TDS) this indicates that among more dissolved solids it finds in the water the abundance of algae will increase.

Canonical analysis between the Protoe Diversity Index with Helminths and Physicochemical Variables (Table 7) gave a negative value for the $\mathrm{pH}$ variable indicating that if the $\mathrm{pH}$ increases it can influence the abundance of these organisms, the electrical conductivity variables and solids dissolved (PPM TDS) have similar positive values which indicates that among greater electrical conductivity and more dissolved solids; the abundance of these organism can increase.

Table 6. Canonical analysis, correlation between algae and physical-chemical variables.

$\begin{array}{cc}\text { PH } & 10994 \\ \text { US_CM } & -448226 \\ \text { PPM } & 35151 \\ \text { TDS } & \end{array}$


Table 7. Canonical analysis, correlation between protozoa with helminths and physical-chemical variables.

PH $\quad-119181$

$\begin{array}{cc}\text { US_CM } & 313392 \\ \text { PPM } & 298139 \\ \text { TDS } & \end{array}$

The data found in this study suggest that the $\mathrm{pH}$ variable is dependent on algae in two determining factors, plant production and wastewater coinciding with what is described by Luzern in 2015 who gives importance to sedimentary acidic acids due to its potential to increase the Amount of organic matter, and for its exclusively phytoplactonic origin. This variation can be explained by the absorption that the algae perform during the day, which take $\mathrm{CO} 2$ of the water, forming with this an acidic means that directly affects the increase in the value of the $\mathrm{pH}$, which brings negative consequences as the production of ammonia From ammonium ions acting as a strong poison for fish and microorganisms (protozoa and helminth).

Bearing in mind the results of the canonical analysis, the correlation between protozoos with helminths and the physical-chemical variables presented in Table No 7, it is evident that there is a directly proportional relationship between the increase in organic matter in the environment, with the presence of algae (Cabrera 2016). Contrary to what happens with protozoa and helminths according to Luzern 2015, by increasing $\mathrm{pH}$ in the environment in which they live, they decrease the possibilities of life for these groups.

We agree in this study with Luzern 2015, who poses that the smallest impurity in water causes conductivity to increase, the cause of this phenomenon is due to the absorption of air gas and reaction with its ions. It has been found that high water conductivity values are related proportionally inverse with the decrease in the algae community; However, it favors the production of organic matter in the middle by increasing the presence of protozoa and helminths. Regarding the higher the content of nutritious salts such as phosphates and nitrates in the waters, the greater the growth of the algae.

\section{CONCLUSION}

The presence of the different genres of microscopic algae in the Water Intakes and the presence of total coliforms, indicate that algae serve as water quality bioindicators as they have the ability to withstand and bioacumulate toxic substances that have an impact on the health of other heterotropic organisms, in addition to showing other factors that can influence the pollution of water sources that other indicators do not show. 


\section{BIBLIOGRAPHY}

Abuhatab A, Y. Donato R, J CH. (2012). Cocconeis placentula y Achnanthidium minutissimum especies indicadoras de arroyos oligotróficos andinos. Caldasia 34 (1): 205-212.

Castro R, D. (2009). Desarrollo de un índice de diatomeas perifíticas para evaluar el estado de los humedales de Bogotá. Trabajo de investigación de Maestría, Universidad Nacional de Colombia. 104 pp.

Cabioc`h J. Floc’h J, Y. Le Toquin A. Boudouresque C, F. Meinesz A. Verlaque M. (1995). Guía de las algas de los mares de Europa: Atlántico y mediterráneo. Barcelona. 1-21 pp.

Cabrera. (2016). "Relación entre materia orgánica, hierro, aluminio y manganeso y las algas acidófilas del Lago Caviahue, Neuquén, Argentina". Facultad de Ciencias Exactas y Naturales. Universidad de Buenos Aires. http://digital.bl.fcen.uba.ar/Download/Tesis/Tesis_5941_Cabrera.pdf

Costa M. Liss P, S. (1999). Photoreduction of Mercury in Sea Water and Its Possible Implications for Hg॰ Air-Sea Fluxes. Marine Chemestry, (68):87-95.

Díaz Q, C. Rivera R, C A. (2004). Diatomeas de pequeños ríos andinos y su utilización Como indicadoras de condiciones ambientales. Caldasia 26 (2): 381-394.

González G, J. (1987). Las algas de Méxicoz. Universidad Nacional Autónoma de México. Ciencias, revista de difusión. ISSN: 0187-6376.

Kolkwitz R. Marsson W, A. (1990). Ecology of Plant Saprobia. Ver dt. Ges 26: 505-519

Levine H, G. The use of seaweeds for monitoring coastal waters. (1984). In E.L. Shubret, editor, Algae as ecological indicators, pp 189-210. Academic Press Inc., London.

Lozano C, G. Parra L, N. Moro R, S. Ramírez J, J. (1999). Inferencias paleolimnológicas del Holoceno con base en diatomeas en la laguna Puente Largo, páramo de Frontino, Antioquia. Pp. 57-116. En: M. T. Flórez y C. G. Lozano (Eds.). Silicofósiles alto andinos. Colciencias, Universidad Nacional de Medellín, Comité de Investigaciones Universidad de Antioquia, Medellín, Colombia.

Luzern. (2015). Valor del agua y sus consecuencias. Algenfrei. Eisengasse 2, CH 6004, Switzerland.

Ramírez A, M. Plata D, Y. (2008). Diatomeas perifíticas en diferentes tramos de dos sistemas lóticos de alta montaña (Páramo de Santurbán, Norte de Santander, Colombia) y su relación con las variables ambientales. Acta Biológica Colombiana 13 (1): 199-216.

Resolución número 2115. (2007). Ministerio de la Protección social; Ministerio de ambiente, vivienda y desarrollo territorial.

Roldán G, P. (1992). Fundamentos de limnología neotropical. Universidad de Antioquia, editor, Colección Ciencia y tecnología, número 1, p 529.

Roldán G, P. (1999). Los macroinvertebrados y su valor como indicadores de la calidad del Agua. Revista Académica Colombiana de Ciencias Exactas, Fisicas y Naturales. https://doi.org/0370-3908. 
Montoya M, Y. Ramírez J, J. Seggecin M, R. (2008). Diatomeas perifíticas de la zona de ritral del río Medellín, Antioquia (Colombia). Revista Actualidades Biológicas 30 (89): 181-189.

Morales D, S. Donato R, J. Castro R, M I. (2010). Respuesta de Navicula rhynchocephala (Bacillariophyceae) al incremento de nutrientes en un arroyo andino (Colombia). Acta Biológica Colombiana 15 (2): 73-78.

Ospina A, N. Peña J, E. (2004). Alternativas de Monitoreo de Calidad de Aguas: Algas como Bioindicadores. Acta Nova, 2(4), 513-517. https://doi.org/10.4067/S0716-078X2007000200008.

Patrick R. (1949). A Proposed Biological Measure of Stream Conditions, based on survey of the Conestoga basin, Lacaster Country, Pennsylvania. Proc. Acad. Nat. Scvi. Philad. 101: 277-341.

Patrick R. (1950). Biological Mesuare of Stream Conditions. Sewage ind.Wastes. 22: 926-939.

Peña S, E J. Palacios P, M L. Ospina A, N. (2005). Algas como indicadoras de contaminación. Editorial Universidad del Valle. 85-84 pp. Libro electrónico http://www.lalibreriadelau.com/biologiaca29_47/libro-algas-como-indicadoras-decontaminacion-p2243.

Pinilla G, A. (2000). Indicadores biológicos en ecosistemas acuáticos continentales de Colombia. p 67. Fundación Universidad de Bogotá Jorge Tadeo Lozano, Bogotá.

Schiewer S. WongM, H. (2000). Ionic strength effects in biosoportion of metals by marine algae. Chemosphere, (41):271-282.

Vélez M, I. Hooghiemstra H. Metcalfe S. Martínez I, Mommersteeg H. (2003). Pollen and diatom based environmental history since the last glacial maximum from the Andean core Fúquene-7. Journal Quaternary Science 18: 17-30.

Vélez M I. Berrío J, C. Hooghiemstra H. Metcalfe S. Marchant R. (2005). Palaeoenvironmental changes during the last ca. 8590 calibrated yr (7800 radiocarbon yr) in the dry forest ecosystem of the Patía Valley, Southern Colombian Andes: a multiproxy approach. Palaeogeography, Palaeoclimatology, Palaeoecology 216: 279-302.

Vélez M, I. Hooghiemstra H. (2005). Fossil and modern diatom assemblages from the savanna lake El Piñal, Colombia: an environmental reconstruction. Diatom Research 20 (2): 387-407.

Wang W. Lewis M, A. (1997). Metal accumulation by aquatic macrophytes. In Plants for Environmental Studies. Lewis Publishers, New York. U.S.A.

Wilcox B. Guinther E. Duin K. Maybaum H. (1998). Manual for watershed health and water quality. Prepared by Geo InSight International, Inc. and Institute for Sustainable Development. Prepared for Marine Corps Base Hawaii MCBH Environmental Affairs Division, under contract to Navy Facilities Engineering Services Center.

Wilson J, G. (1994). The role of bioindicators in estuarine management. Estuarines, 17(1A):94-101. 